François Nkeumi, jeune voix poétique du Cameroun.

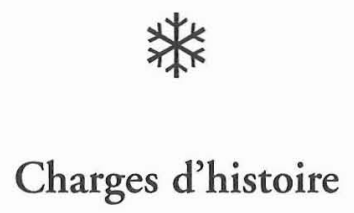

Le Pays

Et

L'homme

Etaient tous les deux

Chargés de tant d'histoire

Ce beau pays

De l'ancien Empire

Cette magnifique contrée

De l'éphémère Fédération

Qui a vu défiler

Tour à tour

Portugais

Hollandais

Et

Français

Pouvait laisser la " porte " de

Gorée

Raconter tout

Ce qu'elle avit vu

Cet homme

Qui confond

Présent et passé

Cet homme

Qui a côtoyé

Les grands de ce monde

Cet homme

Dont la mémoire est chargée

De tant de souvenirs

Est une "légende vivante " 


\section{Et le pays}

Et l'homme

Etaient tous deux

Chargés d'histoire

Car ton histoire

Patriarche

Se confond avec

Celle de ton peuple

Et pour te remercier à jamais

Ils ont à l'unanimité bâptisé

La plus large avenue

De leur cœur

"Boulevard Senghor "

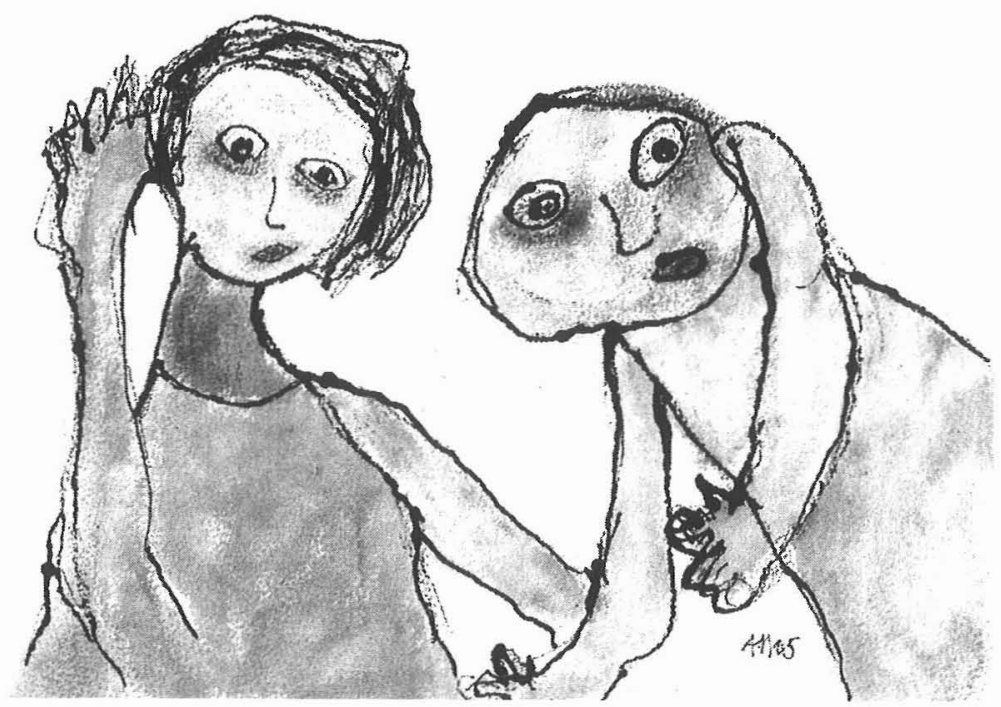

AdAm NidZgorsKI 